\title{
Dehydration reactions of protonated dipeptides containing asparagine or glutamine investigated by infrared ion spectroscopy
}

\author{
Lisanne J.M. Kempkes ${ }^{1}$, Jonathan Martens ${ }^{1}$, Giel Berden ${ }^{1}$, Jos Oomens ${ }^{1,2,{ }^{*}}$ \\ ${ }^{1}$ Radboud University, Institute for Molecules and Materials, FELIX laboratory, Toernooiveld 7c, 6525 ED \\ Nijmegen, The Netherlands \\ ${ }^{2}$ Van 't Hoff Institute for Molecular Sciences, University of Amsterdam, Science Park 904, $1098 \mathrm{XH}$ \\ Amsterdam, the Netherlands
}

\begin{abstract}
The role of specific amino acid side-chains in the fragmentation chemistry of gaseous protonated peptides resulting from collisional activation remains incompletely understood. For small peptides containing asparagine and glutamine, a dominant fragmentation channel induced by collisional activations is, in addition to deamidation, the loss of neutral water. Identifying the product ion structures from $\mathrm{H}_{2} \mathrm{O}$-loss from four protonated dipeptides containing Asn or Gln using infrared ion spectroscopy, mechanistic details of the dissociation reactions are revealed. Several sequential dissociation reactions have also been investigated and provide additional insights into the fragmentation chemistry. While water loss can in principle occur from the C-terminus, the side chain or the amide bond carbonyl oxygen, in most cases the $\mathrm{C}$-terminus was found to detach $\mathrm{H}_{2} \mathrm{O}$, leading to $\mathrm{a}_{2}$-sequence ion with an oxazolone structure for AlaGln, and bifurcating mechanisms leading to both oxazolone and diketopiperazine species for AlaAsn and AsnAla. In contrast, GlnAla expels water from the amide side chain leading to an imino-substituted prolinyl structure.
\end{abstract}

Keywords: Peptide fragmentation mechanisms; IRMPD spectroscopy; $\mathrm{H}_{2} \mathrm{O}$-loss; glutamine; asparagine

Dedication: On the occasion of the $70^{\text {th }}$ birthday of our friend and mentor Terrance $B$. McMahon. 


\section{Introduction}

Tandem mass spectrometry has become an indispensable tool in proteomics as it enables the routine determination of the amino acid sequence of peptides and proteins. This process involves the gas-phase dissociation of the protonated peptide and an analysis of the $\mathrm{m} / \mathrm{z}$ values of the resulting fragment ions. In its most common form, dissociation is accomplished through collisional activation. Collision-induced dissociation (CID) primarily leads to backbone dissociation at the amide bonds, generating sequence ions referred to as b-type ( $\mathrm{N}$-terminal) or y-type (C-terminal)[1-8]. The molecular structures of the resulting b-type ions have been under particularly vigorous debate and it has now been established that b-type ions most often possess an oxazolone structure; for $b_{2}$-fragment ions, a diketopiperazine structure is in some cases formed alternatively [9]. Collision-induced migration of a proton from the most basic site to the amide bond where dissociation occurs, accompanied by a nucleophilic attack by the adjacent backbone carbonyl oxygen or the $\mathrm{N}$-terminal nitrogen are suggested as the reaction pathways to these product ion structures, respectively [10-12]. Deviations from this general behavior have also been observed, for instance, b-ions from GlyGlyGly contain both five- and eight-membered ring structures [13]. Furthermore, the side chain can become actively involved in the reaction mechanism for instance in the formation of $b_{2}$ ions from protonated PheGlnAla (a glutarimide structure) and AlaAsnAla (a succinimide structure) [3].

Small molecule loss upon CID often occurs in addition to backbone fragmentation, where ammonia (deamidation) and water (dehydration) loss are the most common examples. The resulting nonsequence ions are typically not used for protein identification as their $\mathrm{m} / \mathrm{z}$ values are often not recognized by sequencing algorithms $[11,14,15]$. However, since these processes are so common, a mechanistic understanding is of importance and may aid in further improving the interpretation of CID MS/MS spectra and the accuracy of sequencing [1].

In a recent publication,[16] we investigated the deamidation of four very similar dipeptides in order to compare the influence of the side chain identity - Asparagine (Asn) versus Glutamine (Gln) - and the amino acid sequence - AlaXxx versus XxxAla, where Xxx is Asn or Gln. Here, we complement these studies by an investigation of the elimination of water from these same four peptides, so that we are able to completely map out their dissociation chemistry. Structures of the product ions were determined using a combination of mass spectrometry, infrared multiple photon dissociation (IRMPD) spectroscopy and theoretical calculations. IRMPD spectroscopy has previously been used to determine 
the structures of several protonated peptide precursor ions and fragments [17-22], and has proven to be a powerful method to distinguish isomers, (prototropic) tautomers and conformers [18,21,23-33].

Various studies have examined the product structures of water loss from different protonated peptides [34-36], considering in particular the influence of the side chain $[2,3,9]$, peptide length and the identity of the terminal residue in the departing fragment [9]. Note that water loss from an $n$-residue peptide gives a product ion corresponding to the $b_{n}$ sequence ion (at least in terms of its $\mathrm{m} / \mathrm{z}$ value). Water loss from ArgGly and AsnGly has been shown to lead to an oxazolone $b_{2}$ fragment, while for GlyArg it leads to a diketopiperazine structure $[37,38]$. The $b_{2}$ ions of HisAla bifurcate to both oxazolone and diketopiperazine fragment ions [9,39]. However, for protonated GlyGlyGlyGly, water loss occurs from the N-terminal amide group, initiated by a nucleophilic attack of the neighboring amide nitrogen, and hence does not result in an oxazolone structure [40]. While, GlyGly dissociation does not form a b-ion, bions from GlyGlyGly contain both five- and eight-membered ring structures [13]. Tripeptides that contain Asn or Gln have been shown to dissociate along different fragmentation mechanisms [2,3,9].

In order to understand why the formation of $b_{2}$-ions from AsnAlaAla and AlaAsnAla follow different reaction mechanisms, we have selected simplified dipeptide systems. These insights are valuable for understanding the fragmentation behavior of small peptides, and can be extrapolated to explain the fragmentation mechanisms of larger peptides and proteins and can as well be used to predict which reaction mechanisms lead to the formation of $b_{2}$ ions and which lead to the loss of small neutrals.

For the four dipeptides investigated here, Alanine-Asparagine (AlaAsn), Asparagine-Alanine (AsnAla), Alanine-Glutamine (AlaGln) and Glutamine-Alanine (GlnAla), loss of neutral ammonia and water are the dominant reaction channels upon collisional activation. The dehydration reaction of these dipeptides can lead to $b_{2}$-type ions if loss of water occurs from the C-terminus, however, water loss can potentially also occur from the peptide bond carbonyl or from the side-chain. Dehydration via the amide side chain can take place following a reaction that is similar to the reaction mechanism for the loss of ammonia[16]. To support the identification of the dehydrated ion structures, secondary fragmentation reactions were also studied providing further confirmation for the identified structures and allowing us to construct a comprehensive map of the reaction network for each of the peptides is presented. 

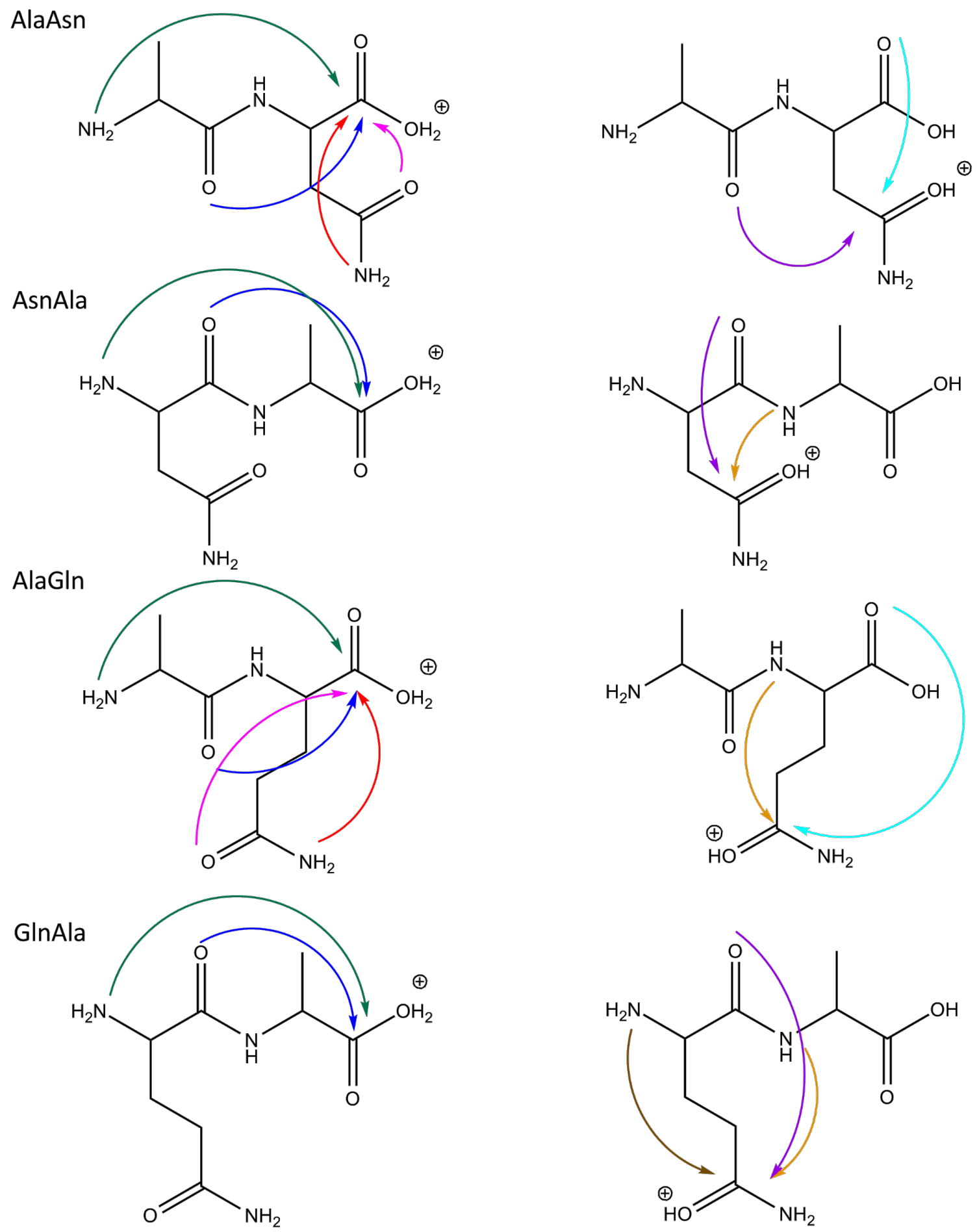

Scheme 1. Possible nucleophilic attack rearrangements leading to dehydration. Both the attack on the Cterminus (left column) as well as on the side chain (right column) are considered. Mechanisms leading to energetically less favorable 4-,7- or higher membered ring structures are not shown here as they were consistently found to lead to high-energy fragment structures. Analogous reaction mechanisms are indicated by arrows of the same color. 


\section{Experimental and computational methods}

\subsection{IRMPD Spectroscopy}

To obtain infrared multiple-photon dissociation (IRMPD) spectra of the dehydrated peptide fragment ions, a modified 3D quadrupole ion trap mass spectrometer (Bruker, AmaZon Speed ETD) was used $[41,42]$ in combination with the Free Electron Laser for Infrared eXperiments (FELIX) [43]. IRMPD spectra were recorded over the $800-2000 \mathrm{~cm}^{-1}$ region. For IRMPD spectra in the hydrogen stretching range (3200-3800 $\mathrm{cm}^{-1}$ ), an optical parametric oscillator (OPO, Laser Vision, Bellevue, USA) was used [44]. Employing FELIX, ions were irradiated with $6 \mu \mathrm{s}$ long macropulses at a repetition rate of $10 \mathrm{~Hz}$, each pulse having an energy of approximately $40 \mathrm{~mJ}$ and a bandwidth of $\sim 0.5 \%$ of the center frequency. The $\mathrm{Nd}$ :YAG-pumped OPO generates $5 \mathrm{~ns}$ long pulses of approximately $15 \mathrm{~mJ}$ at $10 \mathrm{~Hz}$ and has a bandwidth of approximately $3 \mathrm{~cm}^{-1}$. The frequency of FELIX is calibrated using a grating spectrometer and a wavemeter is used for the OPO. IRMPD spectra are corrected for fluctuations of the pulse energy over the scan range assuming a linear power dependence of the fragmentation signal.

Protonated peptide ions were generated using electrospray ionization (ESI) from $10^{-6} \mathrm{M}$ solutions in 50:50 acetonitrile:water with $\sim 0.1 \%$ formic acid added. Collisional activation of the isolated dipeptides for $40 \mathrm{~ms}$ with an amplitude parameter of approximately $0.3 \mathrm{~V}$ generated the $\left[\mathrm{M}+\mathrm{H}-\mathrm{H}_{2} \mathrm{O}\right]^{+}$ions, which were subsequently mass selected and irradiated with two (more for OPO measurements) pulses from the IR laser. The IR induced fragment yield at each wavelength is obtained from five averaged mass spectra and calculated by relating the parent and fragment ion intensities according to $\sum I$ (fragments)/ $/$ I(fragments + parent) $[42,45]$. Peptides were purchased from GeneCust (Luxembourg) and used without any further purification.

\subsection{Computational Chemistry}

Density Functional Theory (DFT) calculations were performed at the B3LYP/6-31++G(d,p) level of theory using Gaussian 09 revision D01 [46]. Molecular geometries of the peptide fragment ions were optimized for different conceivable protonation sites and their linear IR spectra were predicted. Computed harmonic vibrational frequencies were scaled by 0.975 and convoluted with a $25 \mathrm{~cm}^{-1}$ full-width-at-halfmaximum (FWHM) Gaussian line shape to facilitate comparison with experimental spectra. In order to obtain the lowest energy conformers and to explore the potential energy surface, a molecular mechanics/molecular dynamics (MM/MD) approach using AMBER $12[16,41,44,47]$ was applied on each peptide fragment ion. $\mathrm{MS}^{3}$ fragments were considered to be small enough that no $\mathrm{MM} / \mathrm{MD}$ approach 
was required. After an initial MM geometry optimization within AMBER, a simulated annealing procedure up to $500 \mathrm{~K}$ was used to obtain 500 structures. These structures were grouped based on their structural similarity using appropriate rms criteria to give 20-30 candidate structures. These structures were then optimized using the DFT protocol and their scaled harmonic spectra were compared with the experimental spectra. The computational procedure is described in more detail elsewhere $[25,41,44]$.

\section{Results}

\subsection{Dehydrated Alanine-Asparagine, $\left[\text { AlaAsn+H }-\mathrm{H}_{2} \mathrm{O}\right]^{+}$}

As depicted in Scheme 1, several possible mechanisms leading to the expulsion of $\mathrm{H}_{2} \mathrm{O}$ were considered. Table 1 presents the three lowest energy structures arising from these calculations. Additional structures with their relative energies can be found in Table S1 of the Supplementary Information. The colors of the molecules in the tables correspond to the colors of the arrows indicating the nucleophilic attacks in Scheme 1. For each of the resulting structures, multiple protonation sites are conceivable as indicated by numbers $1-6$ in the first column of Table 1 . Structure 1.5, the oxygen-protonated diketopiperazine structure, is the overall lowest energy structure.

Table 1. Calculated relative Gibbs free energies in $\mathrm{kJ} / \mathrm{mol}$ for the different possible isomeric structures resulting from $\mathrm{H}_{2} \mathrm{O}$ loss from protonated AlaAsn, each given for different conceivable protonation sites. The colors of the structures correspond with the colors of the arrows in Scheme 1.

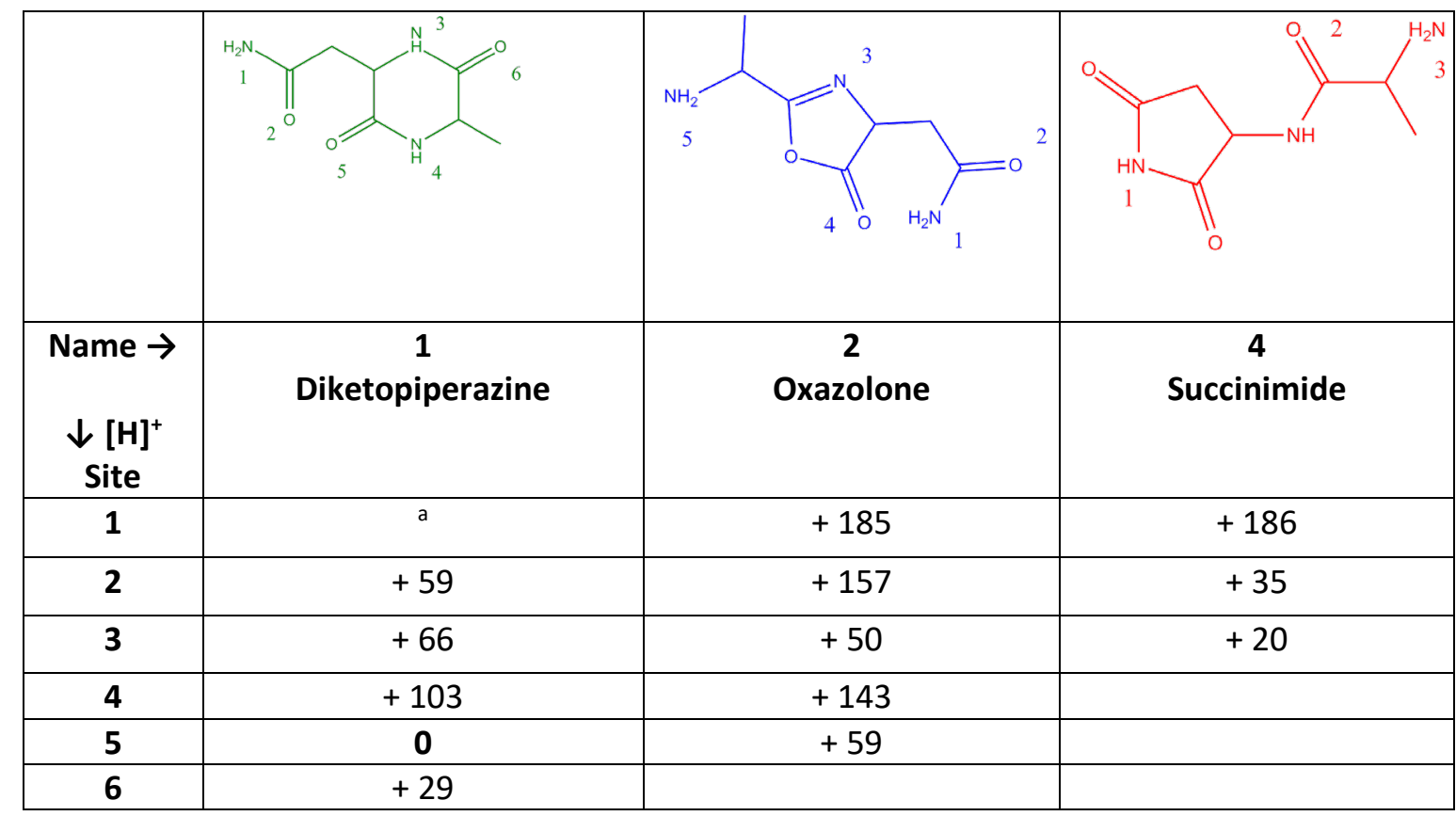

a Proton migrates to position 5 during optimization. 


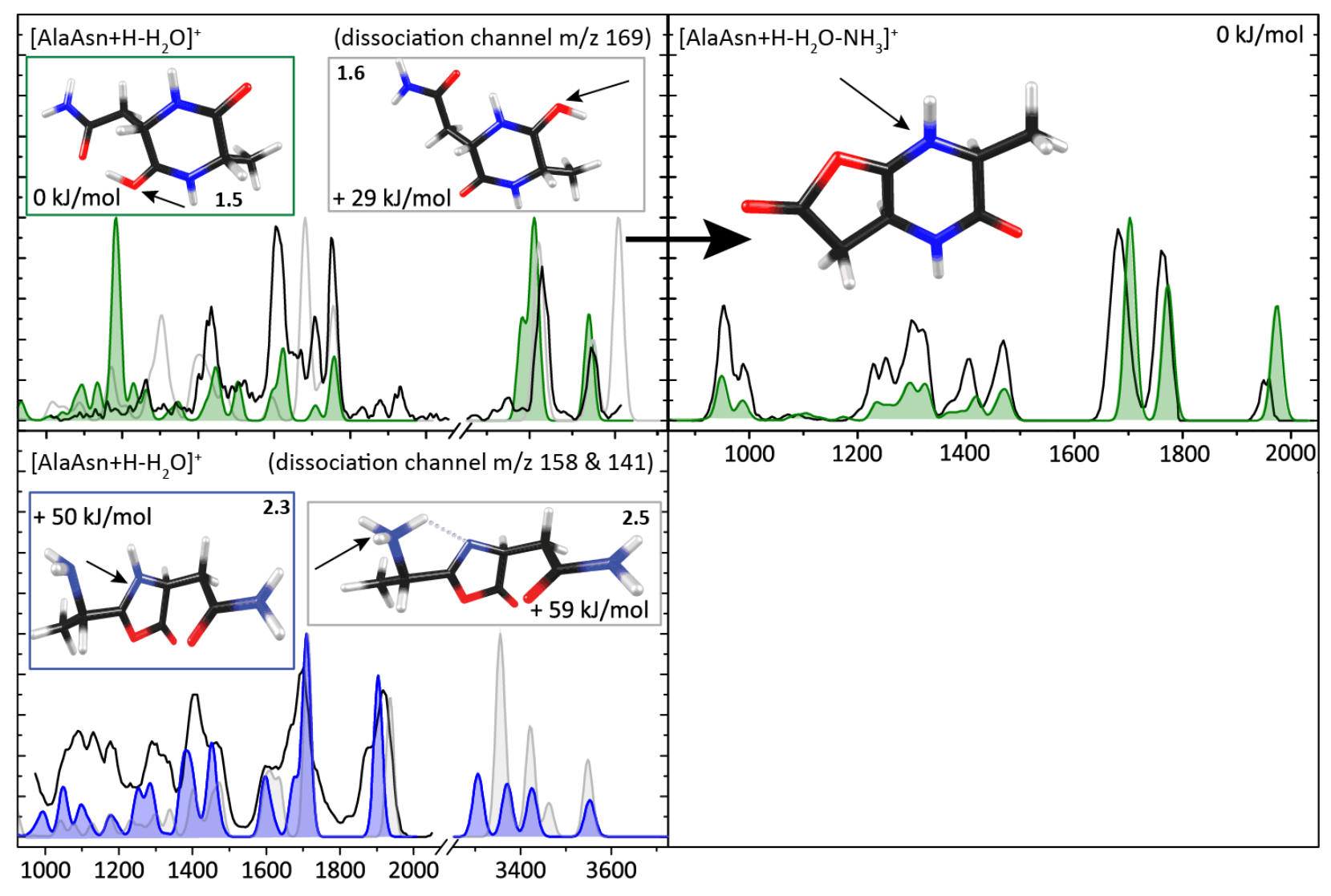

Wavenumber $\left(\mathrm{cm}^{-1}\right)$

Figure 1. IRMPD spectra (black) of [AlaAsn+H-H $\left.\mathrm{H}_{2} \mathrm{O}\right]^{+}$(left panels) and [AlaAsn $\left.+\mathrm{H}-\mathrm{H}_{2} \mathrm{O}-\mathrm{NH}_{3}\right]^{+}$(right panel) compared to calculated spectra. The IRMPD spectra of [AlaAsn+H-H $\left.\mathrm{H}_{2} \mathrm{O}\right]^{+}$in the left panels are generated by plotting the wavelength-dependent fragmentation into the $\mathrm{m} / \mathrm{z} 169$ channel (top, loss of $\mathrm{NH}_{3}$ ) and that into the $\mathrm{m} / \mathrm{z} 158$ and 141 channels summed (bottom, loss of $\mathrm{CO}$ and $\mathrm{CO}+\mathrm{NH}_{3}$ ). Experimental spectra are plotted along with the best matching theoretical spectrum, where colors correspond to Table 1. The spectrum of the [AlaAsn+H- $\left.\mathrm{H}_{2} \mathrm{O}-\mathrm{NH}_{3}\right]^{+} \mathrm{MS}^{3}$ fragment ion (top right) confirms its structure as being formed from the diketopiperazine. Protonation sites are indicated with arrows.

For [AlaAsn+H-H $\left.\mathrm{H}_{2} \mathrm{O}\right]^{+}$, two distinct fragments are produced by IRMPD, one at $\mathrm{m} / \mathrm{z} 169$ (corresponding to loss of $\mathrm{NH}_{3}$, top left panel in Figure 1) and the other at $\mathrm{m} / \mathrm{z} 158$ (loss of $\mathrm{CO}$, bottom left panel). The latter is accompanied by a minor dissociation into $\mathrm{m} / \mathrm{z} 141$ corresponding to additional $\mathrm{NH}_{3}$ loss. Determining the IRMPD yield separately for these two channels gives two distinct IRMPD spectra, suggesting that multiple isomers are present in the population of $\left[\mathrm{AlaAsn}+\mathrm{H}-\mathrm{H}_{2} \mathrm{O}\right]^{+}$, each following distinct fragmentation pathways.

The band near $1925 \mathrm{~cm}^{-1}$ in the spectrum encoded into the $\mathrm{CO}$ and $\mathrm{CO}+\mathrm{NH}_{3}$ loss channels (Figure 1, bottom left) is the characteristic $\mathrm{C}=\mathrm{O}$ stretch of an oxazolone ring thus identifying the oxazolone structure 2. In fact, this band shows a splitting which suggests that the two lowest-energy oxazolone 
tautomers co-exist and the spectrum between 1000 and $1800 \mathrm{~cm}^{-1}$ agrees with the calculated IR spectra of both 2.3 and 2.5. The relative Gibbs free energy difference between them is only $9 \mathrm{~kJ} / \mathrm{mol}$, which makes transfer of the proton from the oxazolone ring to the $\mathrm{N}$-terminus thermodynamically possible as has been previously observed $[9,18]$. The band at $1710 \mathrm{~cm}^{-1}$ is assigned to $C=O$ stretching of the side chain amide and the band around $1600 \mathrm{~cm}^{-1}$ is assigned to $\mathrm{NH}_{2}$ bending at the $\mathrm{N}$-terminus.

In contrast, the absence of the oxazolone band in the spectrum around $1900 \mathrm{~cm}^{-1}$ encoded into the $\mathrm{NH}_{3^{-}}$ loss channel is a strong indication that the carrier has a diketopiperazine structure (1). The small peaks in the $1800-2000 \mathrm{~cm}^{-1}$ range are likely due to minor $\mathrm{NH}_{3}$ loss from the oxazolone structure. Protonation on each of the distinguishable diketopiperazine oxygens leads to different $\mathrm{H}$-bond stabilized structures (1.5 and 1.6) and comparison with their computed spectra in green and grey suggests the presence of more than one tautomer is evident [9]. The band around $1760 \mathrm{~cm}^{-1}$ in the calculated spectra of both tautomers is due to the unprotonated carbonyl $\mathrm{C}=\mathrm{O}$ stretch. The band near $1420 \mathrm{~cm}^{-1}$ is due to $\mathrm{CH}$ bending in the $\mathrm{CH}_{3}$-group. Several weaker bands predicted in the $1000-1400 \mathrm{~cm}^{-1}$ range are barely visible in the experimental spectrum. The intense band predicted at $1180 \mathrm{~cm}^{-1}$ is not observed in the experiment; the computation shows that it is due to a normal mode with dominant $\mathrm{O}-\mathrm{H}^{+} \cdots \mathrm{O}$ bending character, which we suspect to be subject to significant spectral broadening and shifting in the IRMPD spectrum and to poor modelling by the harmonic calculations [48-53]. Other isomers/tautomers have been considered, but no convincing spectral match was found (see Figure S1 in the Supporting Information) and these structures are not further discussed here.

The right panel of Figure 1 shows the IRMPD spectrum of the $\mathrm{MS}^{3}$ fragment $\left[A \text { laAsn }+\mathrm{H}_{-}-\mathrm{H}_{2} \mathrm{O}-\mathrm{NH}_{3}\right]^{+}$at $\mathrm{m} / \mathrm{z}$ 169. Based on the agreement of the experimental spectrum with the predicted spectrum for a structure arising from $\mathrm{NH}_{3}$ loss from the amide side chain of 1, we assign the structure of this secondary fragment as a lactone/diketopiperazine fused ring structure. The band around $1975 \mathrm{~cm}^{-1}$ is due to carbonyl C=O stretching in the lactone ring, the $1775 \mathrm{~cm}^{-1}$ band is assigned to $\mathrm{C}=\mathrm{O}$ stretching in the diketopiperazine ring, and the band near $1710 \mathrm{~cm}^{-1}$ is $\mathrm{CN}$ stretching of the protonated nitrogen. This assignment lends further support to the identification of $\left[\mathrm{AlaAsn}+\mathrm{H}-\mathrm{H}_{2} \mathrm{O}\right]^{+}$as 1 . The intensity of the $\left[\mathrm{AlaAsn}+\mathrm{H}-\mathrm{H}_{2} \mathrm{O}-\mathrm{CO}\right]^{+}$ product was too low to investigate its structure by IRMPD spectroscopy.

Scheme $2 \mathrm{a}$ shows the bifurcating reaction mechanism in the dehydration of protonated AlaAsn suggested by the present spectroscopic observations. Both isomers are formed through $\mathrm{H}_{2} \mathrm{O}$-loss from 
the C-terminus. To form the diketopiperazine isomer, nucleophilic attack occurs from the $\mathrm{N}$-terminus, while the oxazolone isomer is formed via nucleophilic attack from the peptide bond oxygen. These pathways thus follow the well-known $b-y$ fragmentation mechanism for protonated peptides [8]. Subsequent $\mathrm{MS}^{3}$ dissociation of the diketopiperazine expels $\mathrm{NH}_{3}$ from the Asn side chain. The oxazolone isomer expels $\mathrm{CO}$, probably leading to an $a$-type sequence ion, although no spectroscopic information is available here (see further in the discussion of AsnAla).

Assuming that the diketopiperazine structure dissociates exclusively via $\mathrm{NH}_{3}$ loss (into $\mathrm{m} / \mathrm{z} 169$ ) and that the oxazolone dissociates exclusively via loss of $\mathrm{CO}$ and $\mathrm{CO}+\mathrm{NH}_{3}$ (into $\mathrm{m} / \mathrm{z} 158$ and 141), we can use the $\mathrm{CID} \mathrm{MS}^{3}$ spectrum to estimate the relative dissociation rates into the bifurcating oxazolone and diketopiperazine pathways upon dehydration of the precursor peptide [AlaAsn $+\mathrm{H}]^{+}$. Figure S5 in the Supporting Information shows that this ratio is about 4.5 to 1 in favor of the diketopiperazine pathway. 
a) AlaAsn

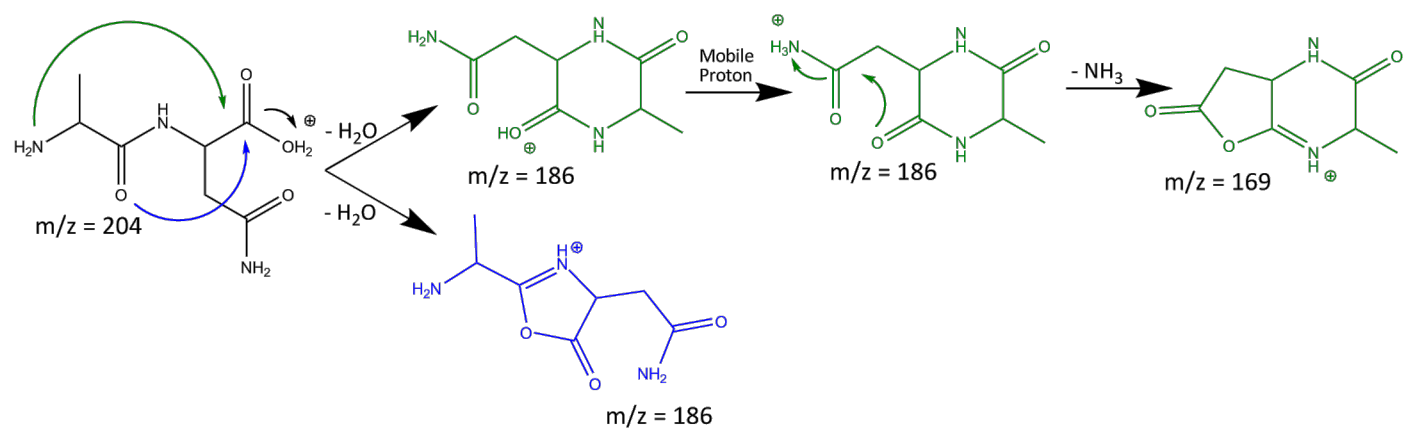

b) AsnAla

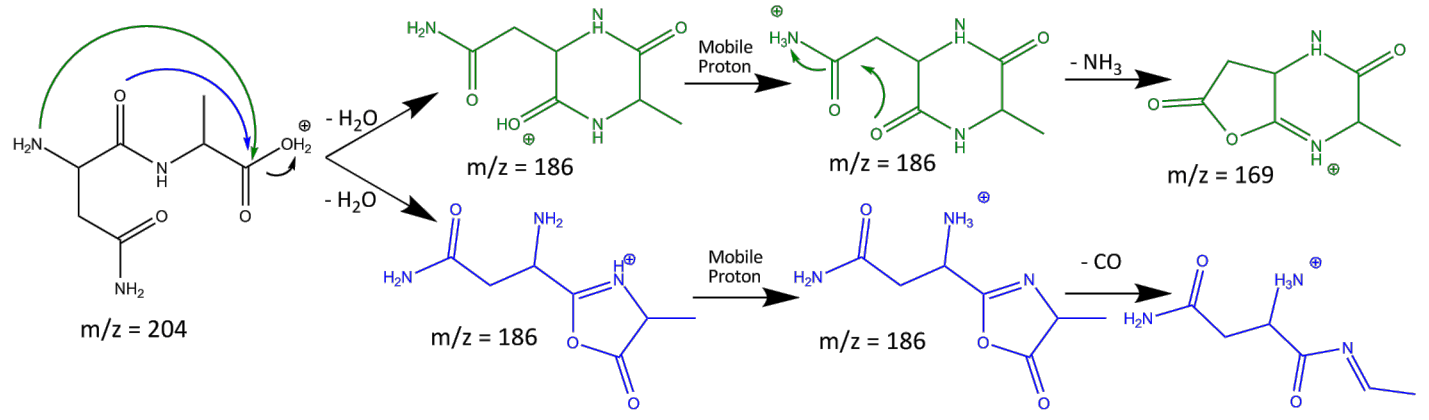

$\mathrm{m} / \mathrm{z}=158$

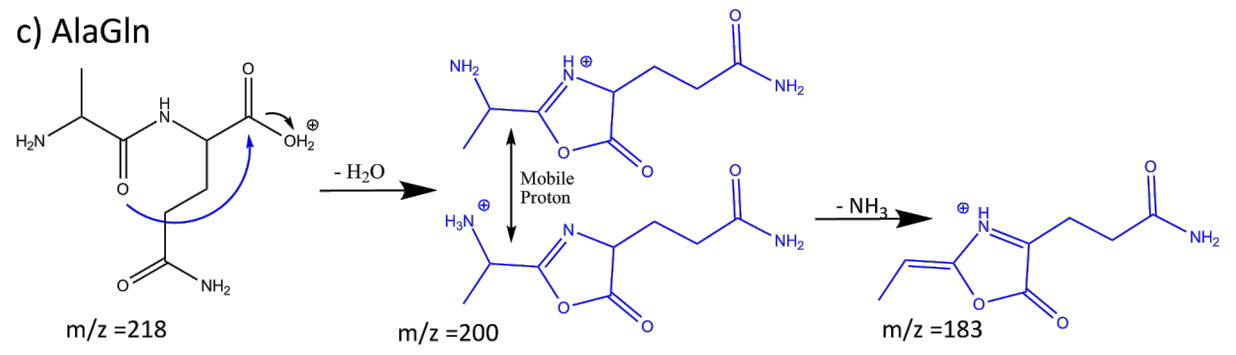

d) GInAla $\quad{ }^{\oplus} \quad \mathrm{m} / \mathrm{z}=182$

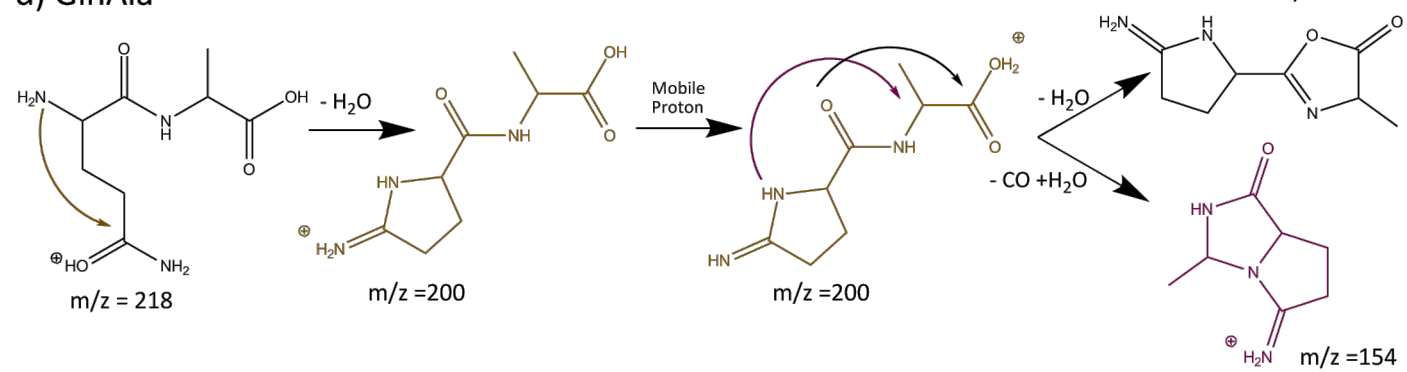

Scheme 2. Proposed reaction mechanisms for $\mathrm{H}_{2} \mathrm{O}$-loss from the dipeptides investigated as derived from the product ion structures identified based on their IRMPD spectra. 


\subsection{Dehydrated Asparagine-Alanine, [AsnAla $\left.+\mathrm{H}-\mathrm{H}_{2} \mathrm{O}\right]^{+}$}

For [AsnAla $\left.+\mathrm{H}-\mathrm{H}_{2} \mathrm{O}\right]^{+}$, Scheme 1 presents four possible reaction mechanisms leading to isomers 6-9, for each of which all potential protonation sites have been considered; computed relative Gibbs free energies are shown in Table 2 for the most prominent ones, with additional structures given in Table S2 in the Sl. Ions $\mathbf{6}$ and $\mathbf{7}$ arise from $\mathrm{H}_{2} \mathrm{O}$ loss from the C-terminus, while $\mathbf{8}$ and $\mathbf{9}$ form upon $\mathrm{H}_{2} \mathrm{O}$ loss from the side chain. Figure 2 shows the IRMPD spectrum of the dehydrated product ion [AsnAla $\left.+\mathrm{H}-\mathrm{H}_{2} \mathrm{O}\right]^{+}$at $\mathrm{m} / \mathrm{z}$ 186, with the IR dissociation into channel m/z 169 (loss of $\mathrm{NH}_{3}$ ) and that into $\mathrm{m} / \mathrm{z} 158+\mathrm{m} / \mathrm{z} 141$ (loss of $\mathrm{CO}$ and $\mathrm{CO}+\mathrm{NH}_{3}$ ) again plotted separately.

Table 2. Calculated relative Gibbs free energies in $\mathrm{kJ} / \mathrm{mol}$ for isomeric structures of the $\mathrm{H}_{2} \mathrm{O}$-loss product from protonated AsnAla for different protonation sites.

\begin{tabular}{|c|c|c|c|}
\hline $\begin{array}{l}\text { Name } \rightarrow \\
\downarrow[H]^{+} \\
\text {Site }\end{array}$ & 6 diketopiperazine & $7 \quad$ oxazolone & $\begin{array}{l}9 \\
\text { iminopyrrolidinone }\end{array}$ \\
\hline 1 & +72 & +198 & +571 \\
\hline 2 & +20 & +164 & +146 \\
\hline 3 & $\mathrm{a}$ & +58 & +79 \\
\hline 4 & +115 & $+43^{b}$ & +13 \\
\hline 5 & 0 & +198 & \\
\hline 6 & +48 & & \\
\hline
\end{tabular}

a Proton migrates to position 2 during optimization.

${ }^{b}$ Multiple conformers identified; lowest energy is listed.

The spectra encoded into each of these mass channels are substantially different, suggesting again two different $\mathrm{m} / \mathrm{z} 186$ precursor ion structures to co-exist. The spectrum observed in channel $\mathrm{m} / \mathrm{z} 169$ (top left in Figure 2) is attributed to diketopiperazine structure 6. Note that head-to-tail cyclization of AlaAsn and AsnAla upon $\mathrm{H}_{2} \mathrm{O}$-loss lead to the same structure, so that $\mathbf{6}$ is in fact equal to 1 . The experimental 
spectrum matches reasonably well with the spectrum computed for tautomer 6.5, with the sharp features in 1400-1800 cm-1 range reproduced well and the $1000-1400 \mathrm{~cm}^{-1}$ range characterized by a series of weaker and unresolved bands. The strong band in the computed spectrum near $1180 \mathrm{~cm}^{-1}$ is not observed in the experiment as it is due to a normal mode with substantial $\mathrm{O}-\mathrm{H}^{+} \ldots \mathrm{O}$ bending character, as discussed above. Our structure assignment is thus the same as that for the [AlaAsn+H$\left.\mathrm{H}_{2} \mathrm{O}\right]^{+}$fragment ion presented in Figure 1, top left panel. Although the sharp, strong bands in the two experimental spectra coincide closely, discrepancies between the two experimental spectra are also observed. We attribute these discrepancies to the different laser pulse energies used in both experiments, with that for the $\left[\mathrm{AlaAsn}+\mathrm{H}-\mathrm{H}_{2} \mathrm{O}\right]^{+}$fragment being approximately three times lower, suppressing the weaker bands in the spectrum. The IRMPD spectrum of the $\mathrm{MS}^{3}$ fragment ion [AsnAla $\left.+\mathrm{H}-\mathrm{H}_{2} \mathrm{O}-\mathrm{NH}_{3}\right]^{+}$in the top right panel of Figure 2 suggests that its structure is indeed identical to that established for $\left[\mathrm{AlaAsn}+\mathrm{H}-\mathrm{H}_{2} \mathrm{O}-\mathrm{NH}_{3}\right]^{+}$and thus provides further support for the structural identification of the $\mathrm{MS}^{2}$ ion.

The IRMPD spectrum derived from IR induced dissociation channels $\mathrm{m} / \mathrm{z} 158$ and 141 (Figure 2, bottom left) possesses a strong and diagnostic feature centered around $1900 \mathrm{~cm}^{-1}$, suggesting an oxazolone structure. As was seen for $\left[\mathrm{AlaAsn}+\mathrm{H}-\mathrm{H}_{2} \mathrm{O}\right]^{+}[9,18]$, this feature is broadened and likely consists of two unresolved bands due to two oxazolone tautomers, 7.3 and 7.4, whose calculated spectra are reproduced in grey and blue. For $7.4(+73 \mathrm{~kJ} / \mathrm{mol})$, an alternative conformer substantially lower in energy $(+43 \mathrm{~kJ} / \mathrm{mol})$ was identified and its computed spectrum is shown in Figure $\mathrm{S} 2$ in the $\mathrm{SI}$. The two spectra differ primarily around $1700 \mathrm{~cm}^{-1}$, but the experimental spectrum does not allow us assign either one or the other conformer, especially when taking into account the additional contribution from 7.3, which also has a strong band in this range.

The oxazolone fragment undergoes $\mathrm{MS}^{3}$ dissociation by sequential CO-loss, as is common for oxazolone $b$-type sequence ions [8]. The spectrum of this $\mathrm{MS}^{3}$ fragment ion (bottom right in Figure 2) exhibits bands at $1747 \mathrm{~cm}^{-1}, \mathrm{C}=0$ stretching of the peptide linkage, $1691 \mathrm{~cm}^{-1}, \mathrm{C}=\mathrm{O}$ stretching of the side chain amide, $1628 \mathrm{~cm}^{-1}$, imine $\mathrm{C}=\mathrm{N}$ stretching, and $1619 \mathrm{~cm}^{-1}, \mathrm{NH}$ bending in the $\mathrm{NH}_{3}$ group. The ion thus has the typical imine structure of $a$-type sequence ions, though with the proton on the $\mathrm{N}$-terminus [54].

Scheme $2 \mathrm{~b}$ summarizes the suggested reaction mechanism for the loss of $\mathrm{H}_{2} \mathrm{O}$ from protonated AsnAla and the sequential losses of $\mathrm{NH}_{3}$ and $\mathrm{CO}$. Dehydration of protonated AsnAla occurs on the C-terminus 
and follows bifurcating pathways analogous to those identified for protonated AlaAsn, leading to oxazolone and diketopiperazine isomers. Further activation of the diketopiperazine expels $\mathrm{NH}_{3}$ from the Asn side chain, forming a 5/6 membered bicyclic structure. In contrast, the oxazolone eliminates CO forming a linear $a$-type sequence ion incorporating an imine group. Inspection of the CID MS ${ }^{3}$ spectrum (Figure S6) suggests relative dissociation rates into the diketopiperazine and oxazolone pathways of 2:1 for dehydration of protonated AsnAla. Although these dissociation pathways are analogous to those of protonated AlaAsn, the relative rates into the two bifurcating pathways are significantly different.

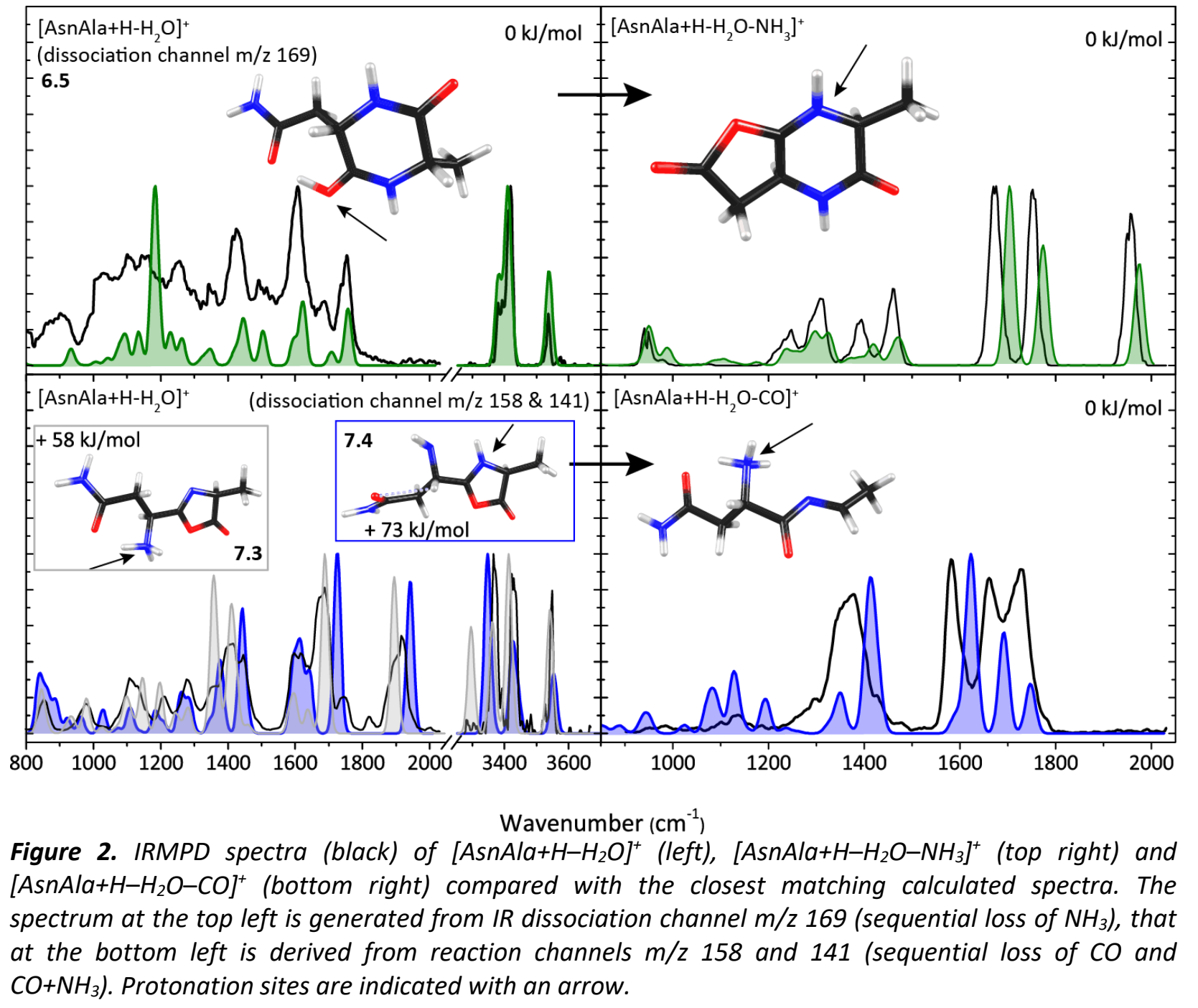

\subsection{Dehydrated Alanine-Glutamine [AlaGln+H $\left.-\mathrm{H}_{2} \mathrm{O}\right]^{+}$}

Six possible reaction pathways for the dehydration of protonated AlaGln are indicated in Scheme 1, leading to five potential structures for the dehydrated ion shown in Tables 3 and S3 in the SI. 
Nucleophilic attack of the side chain oxygen on the C-terminus and nucleophilic attack of the C-terminal oxygen on the side chain both lead to 13.

IRMPD of $\left[\mathrm{AlaGln}+\mathrm{H}-\mathrm{H}_{2} \mathrm{O}\right]^{+}$induces only one fragment at 17 mass units below the precursor ion. Although analogy with the Asn-containing systems above would suggest ammonia-loss to be evidence for a diketopiperazine structure, the IR spectrum recorded is typical for an oxazolone fragment. Figure 3 shows the experimental IRMPD spectrum (black) compared with calculated IR spectra for the global minimum structure $\mathbf{1 0 . 6}$ (green, top left) and for the oxazolone alternatives $\mathbf{1 1 . 3}$ (dark blue, bottom left) and 11.5 (light grey, bottom left). The band near $1950 \mathrm{~cm}^{-1}$ is typical for an oxazolone moiety. A splitting of this band is clearly observed, suggesting the co-existence of two tautomers: $\mathbf{1 1 . 3}$ with protonation on the oxazolone nitrogen and $\mathbf{1 1 . 5}$ with protonation at the $\mathrm{N}$-terminus, the latter being only $6 \mathrm{~kJ} / \mathrm{mol}$ more stable than the former $[9,18]$. For 11.3 , the band at $1650 \mathrm{~cm}^{-1}$ corresponds to $\mathrm{N}-\mathrm{H}$ bending at the oxazolone ring and that at $1665 \mathrm{~cm}^{-1}$ to $\mathrm{N}-\mathrm{H}$ bending at the $\mathrm{N}$-terminus. For 11.5 , the bands at $1630 \mathrm{~cm}^{-1}$ and $1520 \mathrm{~cm}^{-1}$ are assigned to $\mathrm{N}-\mathrm{H}$ bending vibrations at the $\mathrm{N}$-terminus.

Table 3. Calculated relative Gibbs free energies in $\mathrm{kJ} / \mathrm{mol}$ for potential ion structures resulting from $\mathrm{H}_{2} \mathrm{O}$ loss from protonated AlaGln, each given for different potential protonation sites.

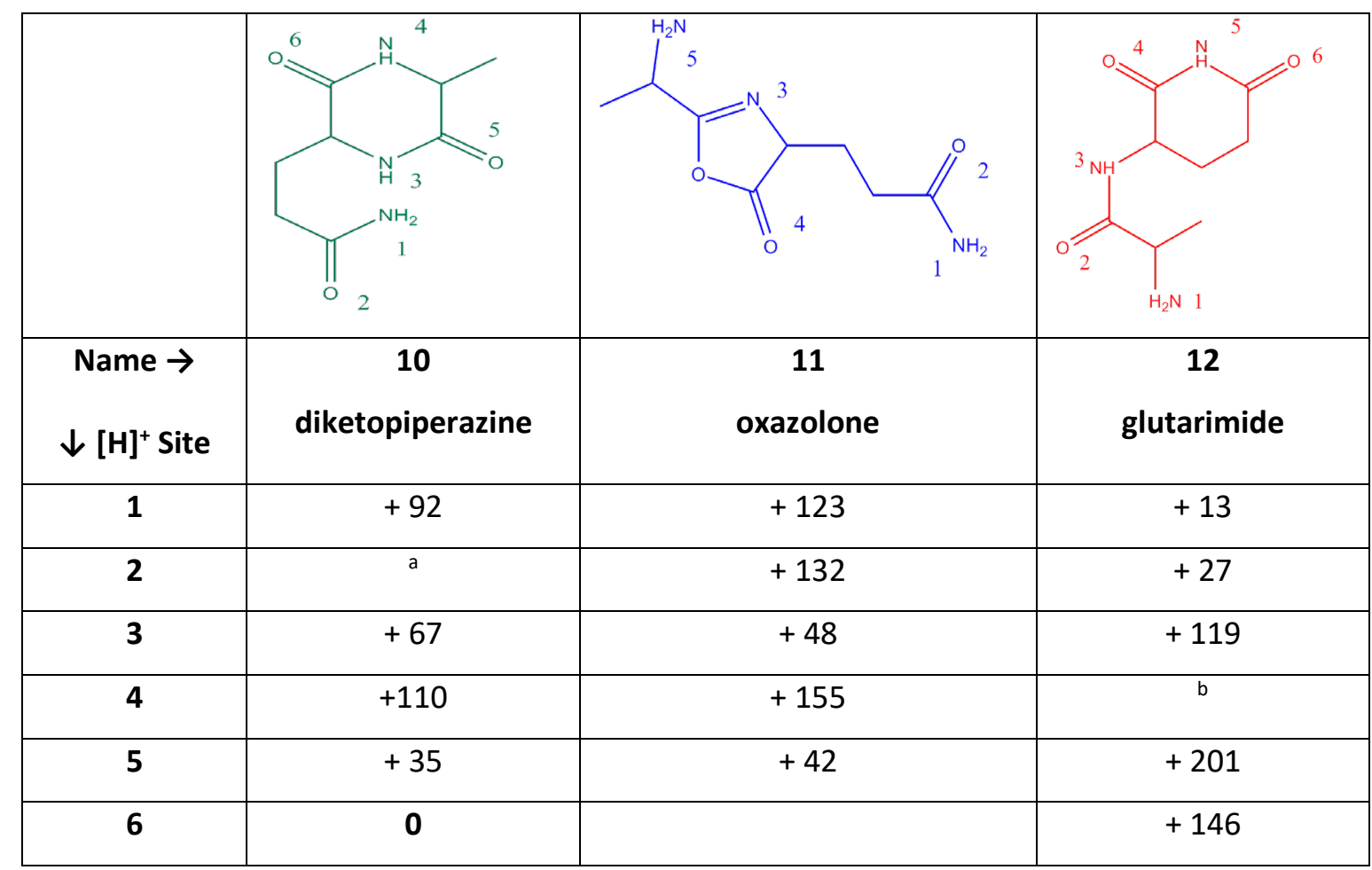

a Proton migrates to position 6 during optimization.

${ }^{b}$ Proton migrates to position 2 during optimization. 


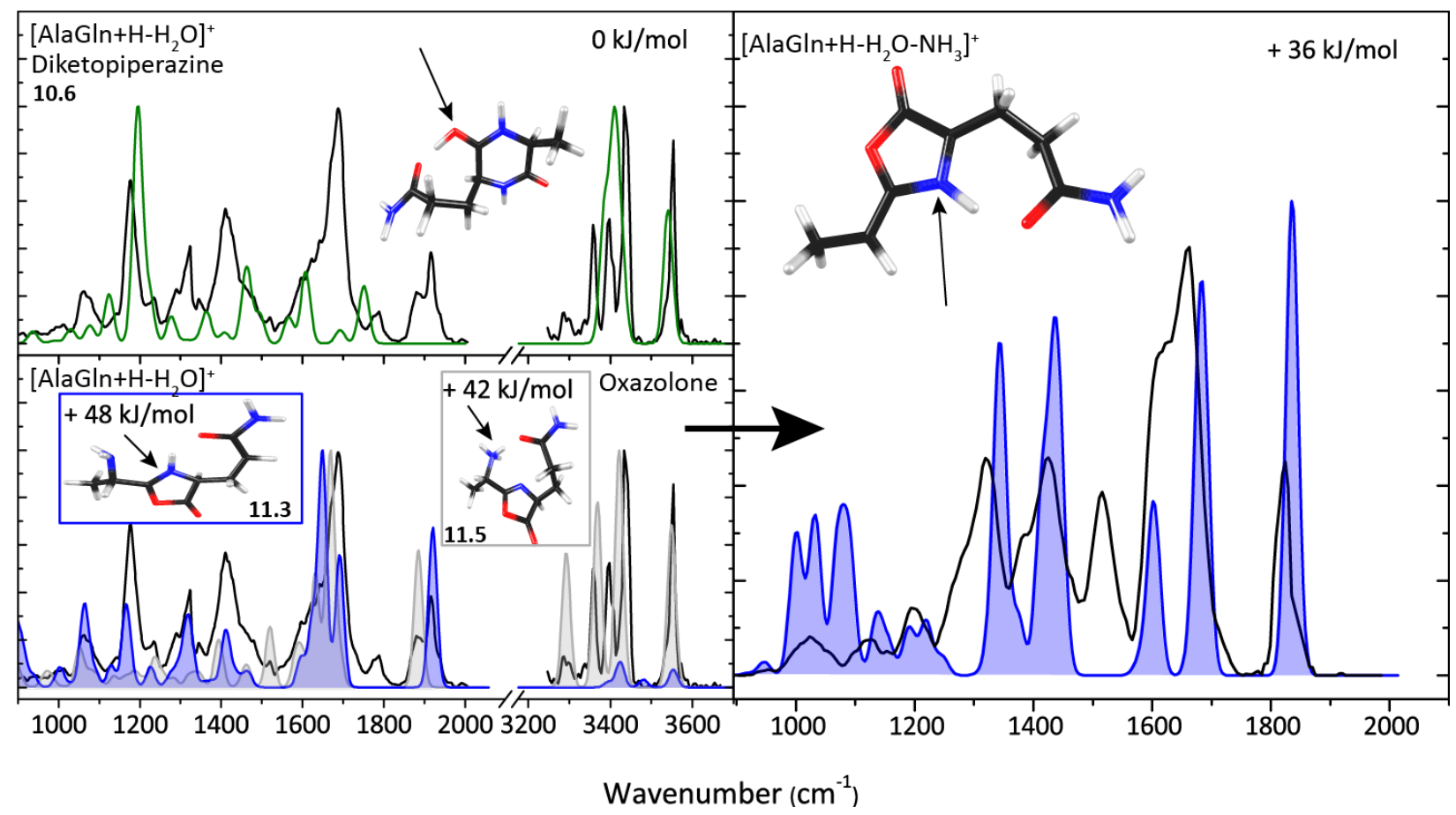

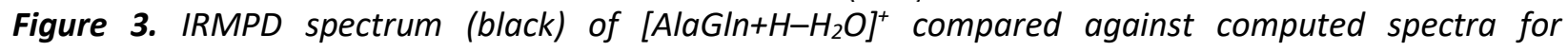
diketopiperazine 10.6 (top left) and oxazolones 11.3 and 11.5 (bottom left). The IRMPD spectrum for the [Ala $\left.\mathrm{In}+\mathrm{H}-\mathrm{H}_{2} \mathrm{O}-\mathrm{NH}_{3}\right]^{+} \mathrm{MS}^{3}$ fragment ion (right) provides further evidence for an oxazolone structure.

The good match of the experimental spectrum with the oxazolone (11.3 and 11.5) spectrum suggests that the diketopiperazine structure (10.6) is at best a minor contributor to the population, in contrast with the observations for the Asn analogue. The band at $1755 \mathrm{~cm}^{-1}$ in the computed spectrum of $\mathbf{1 0 . 6}$ and the weak band near $1780 \mathrm{~cm}^{-1}$ in the observed spectrum that remains unexplained by the oxazolone structures may hint at such a small fraction of diketopiperazine, although both diketopiperazine and oxazolone structures would have to decay by $\mathrm{NH}_{3}$-loss in this case.

The right panel of Figure 3 shows the IRMPD spectrum of the $\mathrm{MS}^{3}$ fragment ion $\left[\mathrm{AlaGln}+\mathrm{H}-\mathrm{H}_{2} \mathrm{O}-\mathrm{NH}_{3}\right]^{+}$at $\mathrm{m} / \mathrm{z}$ 183. Comparison with theoretical spectra suggests that $\mathrm{NH}_{3}$ is detached from the oxazolone structure at the $\mathrm{N}$-terminus. The band at $1835 \mathrm{~cm}^{-1}$ is due to $\mathrm{C}=\mathrm{O}$ stretching in the oxazolone ring, that at $1685 \mathrm{~cm}^{-1}$ is attributed to $\mathrm{C}=\mathrm{O}$ stretching in the side chain and the band at $1600 \mathrm{~cm}^{-1}$ is due to $\mathrm{N}-\mathrm{H}$ bending in the side chain.

Scheme 2c summarizes the reaction mechanism. As for the Asn-containing dipeptides, water is lost from the C-terminus, but in this case it leads exclusively to an oxazolone structure. Unlike the oxazolone 
structures formed from the Asn-containing dipeptides, secondary fragmentation of the oxazolone ion involves the elimination of $\mathrm{NH}_{3}$ rather than $\mathrm{CO}$.

\subsection{Dehydrated Glutamine-Alanine, [GlnAla $\left.+\mathrm{H}-\mathrm{H}_{2} \mathrm{O}\right]^{+}$}

Peptides having Glu or Gln as their N-terminal residue are known for their deviating reaction mechanisms.[16,55-58] In particular, $\mathrm{NH}_{3}$-loss from peptides with an $\mathrm{N}$-terminal GIn residue and $\mathrm{H}_{2} \mathrm{O}$ loss from peptides with an N-terminal Glu residue has been shown to form fragments with a pyroglutamyl moiety at the $\mathrm{N}$-terminus $[55,57,58]$. Nucleophilic attack by the $\mathrm{N}$-terminal nitrogen onto the side-chain $\delta$-carbon atom is in both cases the modus operandi. Moreover, it has been previously suggested that doubly-protonated peptide ions that contain glutamine at the $\mathrm{N}$-terminus and a basic or neutral amino acid at the C-terminus eliminate an $\mathrm{H}_{2} \mathrm{O}$ molecule from the $\mathrm{Gln}$ side chain $[55,57,58]$. However, the same singly charged peptides were reported to eliminate $\mathrm{NH}_{3}[57,58]$. The mechanism proposed for the reaction is a nucleophilic attack of the $\mathrm{N}$-terminal nitrogen on the glutamine side chain leading to the loss of an $\mathrm{H}_{2} \mathrm{O}$ molecule [58]. This mechanism follows the brown arrow in Scheme 1 and leads to the formation of structure 17, which we shall designate by its imino-substituted proline residue. Here we follow the loss of $\mathrm{H}_{2} \mathrm{O}$ from singly charged GInAla.

Table 4 as well as Table S4 in the SI list the five structures resulting from the reaction mechanisms proposed on the bottom row of Scheme 1. Ion 17.1, the imino-prolinyl structure protonated on the imino nitrogen, is the global minimum. Structures $\mathbf{1 5}$ and $\mathbf{1 6}$ are the isomeric $b_{2}$-type ions resulting from $\mathrm{H}_{2} \mathrm{O}$ loss from the $\mathrm{C}$-terminus. Ions $\mathbf{1 8}$ and $\mathbf{1 9}$ are alternative structures resulting from a nucleophilic attack on the side chain and are not b-type ions.

Figure 4 compares the experimental spectrum of $\left[\mathrm{GlnAla}+\mathrm{H}-\mathrm{H}_{2} \mathrm{O}\right]^{+}$with the computed spectrum for imino-prolynyl structure 17.1. From the favorable agreement between experimental and theoretical spectra particularly in the $1000-2000 \mathrm{~cm}^{-1}$ range, we conclude that in contrast to the other dipeptides in this study, protonated GInAla eliminates $\mathrm{H}_{2} \mathrm{O}$ from the $\mathrm{Gln}$ side chain and not from the C-terminus. Further support for this assignment comes from the computed spectra for diketopiperazine (15) and oxazolone (16) structures, which show poor agreement with experiment, see Figure S4 in the SI. Moreover, the presence of a carboxylic acid group in 17, but not in 15 and 16, can explain the observation of $\mathrm{H}_{2} \mathrm{O}$ loss as the $\mathrm{MS}^{3}$ channel, which was not observed for the other dipeptides in this study. As Table 4 indicates, the Gibbs free energies of the oxazolone and diketopiperazine structures are at least 54 and $35 \mathrm{~kJ} / \mathrm{mol}$ higher than the imino-prolinyl structure, respectively. 
Table 4. Calculated relative Gibbs free energies in $\mathrm{kJ} / \mathrm{mol}$ for possible structures resulting from $\mathrm{H}_{2} \mathrm{O}$ loss from protonated GInAla, each given for different protonation sites.

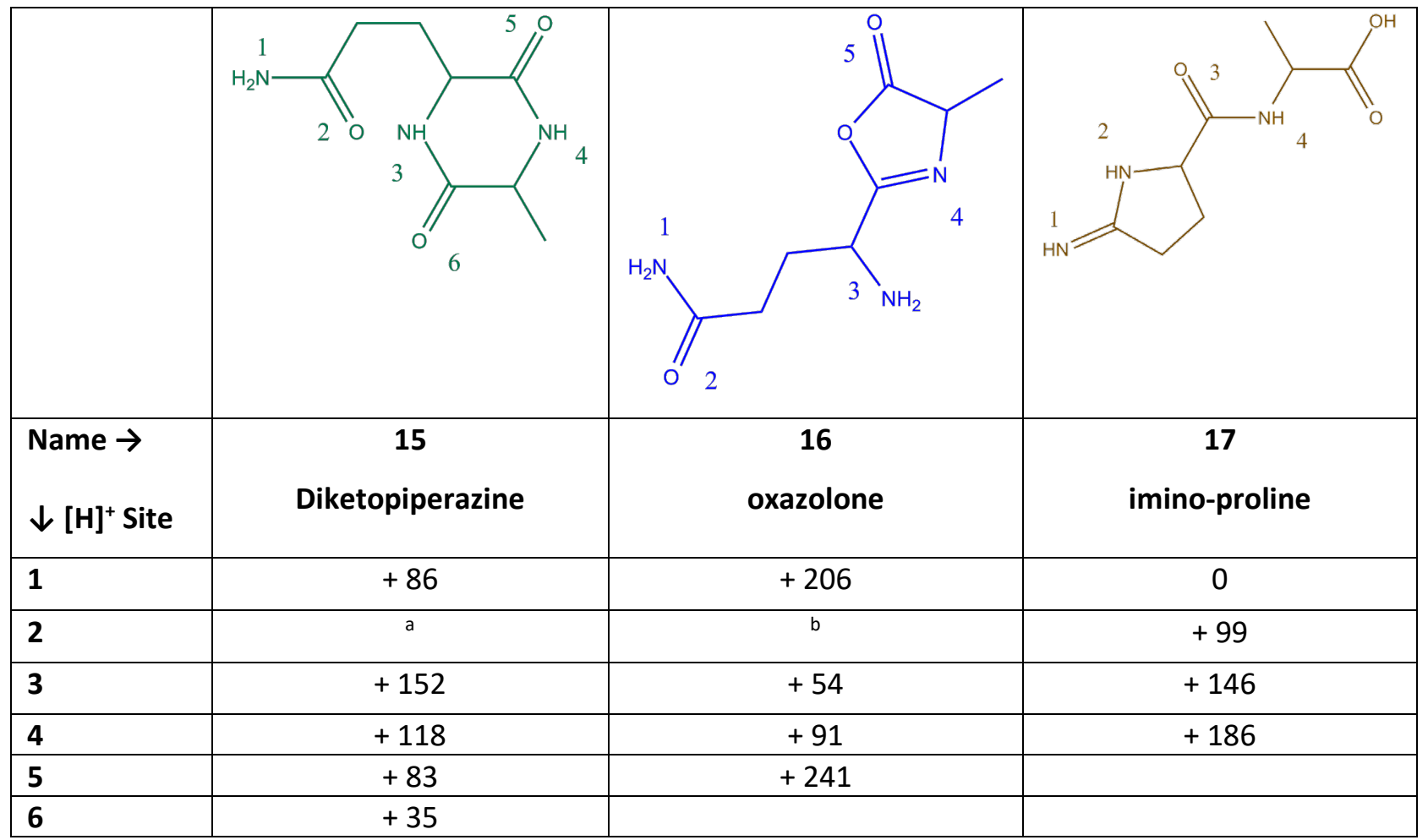

a Proton migrates to position 6 during optimization.

${ }^{\mathrm{b}}$ Proton migrates to position 3 during optimization.

In the computed spectrum of $\mathbf{1 7 . 1}$, the band around $1730 \mathrm{~cm}^{-1}$ corresponds to unresolved carboxyl and amide $\mathrm{C}=\mathrm{O}$ stretches and the band at $1684 \mathrm{~cm}^{-1}$ is due to $\mathrm{NH}_{2}$ bending. The band at $1506 \mathrm{~cm}^{-1}$ is due to $\mathrm{NH}$ bending of the peptide bond. The spectrum in hydrogen stretching range matches poorly with the computation, but we suspect that this is due to threshold effects, where excitation with the OPO laser is unable to reach up to the dissociation threshold at most frequencies.

Further support for our structural assignment is provided by analysis of the subsequent $\mathrm{MS}^{3}$ fragments. Secondary $\mathrm{CID}$ channels are loss of $\mathrm{H}_{2} \mathrm{O}$ and $\mathrm{H}_{2} \mathrm{O}+\mathrm{CO}$. The second $\mathrm{H}_{2} \mathrm{O}$ is eliminated from the $\mathrm{C}$-terminus leading to the formation of an oxazolone moiety, giving the structure shown in the lower left panel of Figure 4. The computed IR spectrum for this structure is seen to match fairly well with the experimental spectrum for this $\mathrm{MS}^{3}$ ion in terms of frequencies, although relative intensities deviate somewhat. The band at $1880 \mathrm{~cm}^{-1}$ is due to the oxazolone $\mathrm{C}=\mathrm{O}$ stretch and the peak at $1697 \mathrm{~cm}^{-1}$ is due to the $\mathrm{CN}$ stretch 
of the protonated imine moiety. The predicted spectrum for the $\left[\mathrm{G} \ln \mathrm{Ala}+\mathrm{H}-\mathrm{H}_{2} \mathrm{O}-\mathrm{CO}\right]^{+} \mathrm{MS}^{3}$ ion is also in fair agreement with the experiment in terms of frequencies, although again relative intensities deviate substantially. We suspect that threshold effects in the IRMPD process are at the origin of these deviations. The band at $1800 \mathrm{~cm}^{-1}$ is due to the $\mathrm{C}=0$ stretch and that at $1690 \mathrm{~cm}^{-1}$ to a bending vibration of the amino.group.

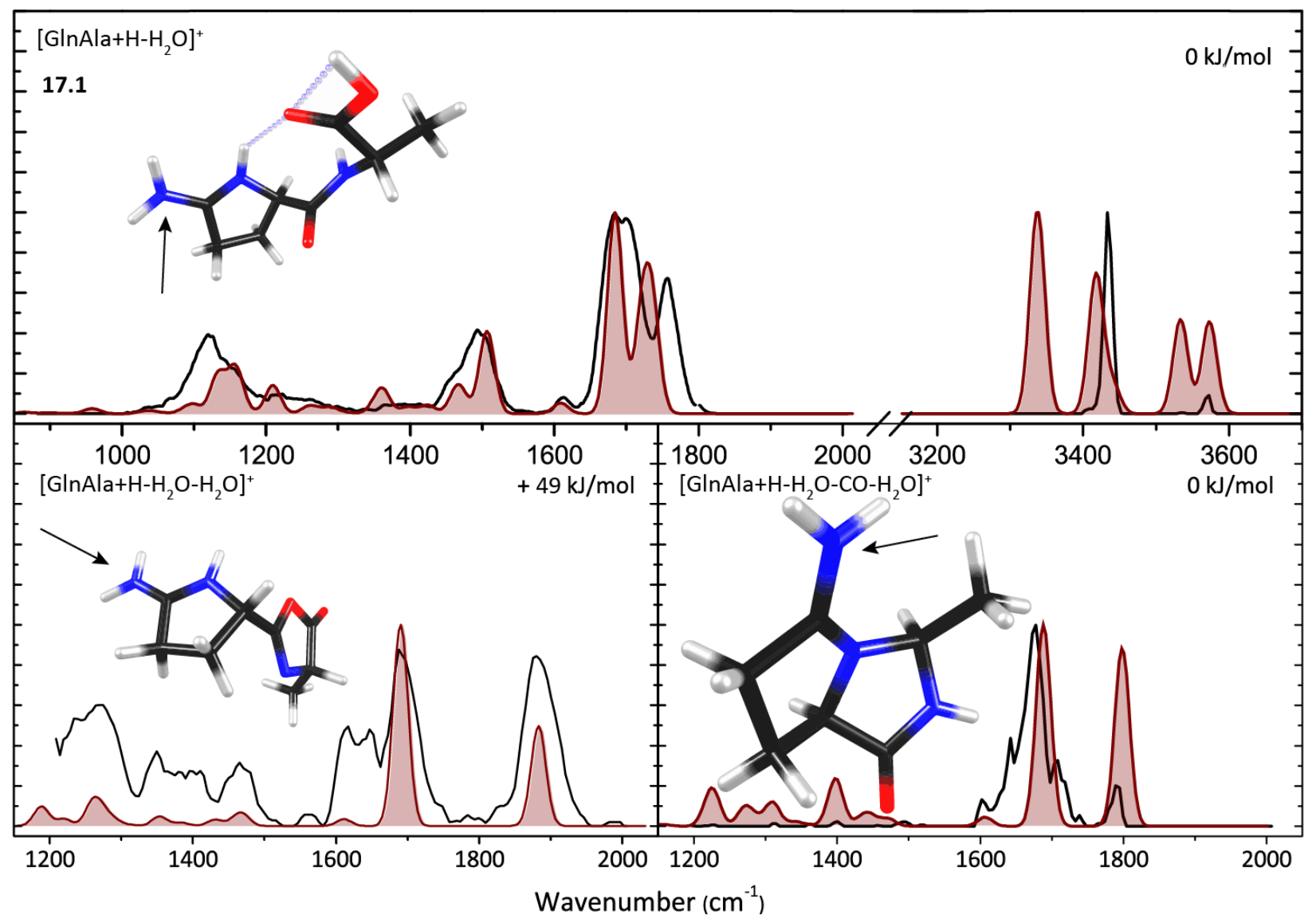

Figure 4. Experimental IRMPD spectrum of the [GInAla+H- $\left.\mathrm{H}_{2} \mathrm{O}\right]^{+} \mathrm{MS}^{2}$ ion (top) and the [GInAla+H-H $\mathrm{H}_{2} \mathrm{O}$ $\left.\mathrm{H}_{2} \mathrm{O}\right]^{+} \mathrm{MS}^{3}$ ion (bottom left) and [GInAla $\left.+\mathrm{H}-\mathrm{H}_{2} \mathrm{O}-\mathrm{CO}-\mathrm{H}_{2} \mathrm{O}\right]^{+}$(bottom right) $\mathrm{MS}^{3}$ ions, compared against the best matching computed spectra. The relatively poor match between experimental and computed spectra in the $\mathrm{H}$-stretching range for the $\mathrm{MS}^{2}$ fragment is tentatively attributed to the lower pulse energy of the OPO and/or a relatively high threshold to dissociation for this specific species, which would enhance non-linear effects and prevent excitation to above the threshold on some of the predicted resonances.

Scheme $2 \mathrm{~d}$ presents the suggested reaction mechanism for the dehydration of protonated GInAla and the suggested pathway for sequential loss of $\mathrm{H}_{2} \mathrm{O}$ and $\mathrm{CO}+\mathrm{H}_{2} \mathrm{O}$. We conclude that nucleophilic attack occurs from the $\mathrm{N}$-terminus on the glutamine side chain. Dehydration follows the same mechanism as observed for deamidation of the peptide $[16,55,58,59]$. Moreover, this mechanism is also analogous to deamidation of the GIn amino acid and the dehydration of the Glu amino acid [25]. After dehydration of 
protonated GInAla, sequential fragmentation proceeds via two parallel mechanisms, one leading to loss of $\mathrm{H}_{2} \mathrm{O}$ from the C-terminus and the other leading to loss of $\mathrm{H}_{2} \mathrm{O}$ and $\mathrm{CO}$.

\section{Conclusions}

Experimental infrared ion spectroscopy combined with quantum-chemical calculations has enabled us to assign the product ion structures resulting from $\mathrm{H}_{2} \mathrm{O}$ loss from a series of protonated dipeptides containing Asn or Gln. As well, the structures of several $\mathrm{MS}^{3}$ fragments were elucidated. From the assigned product ion structures we suggest the reaction mechanisms involved. Combined with our previous study on $\mathrm{NH}_{3}$ loss from these peptides,[16] an extensive molecular structure map of the reaction channels after $\mathrm{MS}^{\mathrm{n}}$ can be constructed as shown in Figure 5.

Our earlier study demonstrated that the deamidation reactions of these dipeptides take place from the Asn or Gln side chain. If we compare the reaction mechanisms assigned for the deamidation reaction with the mechanisms proposed here for the dehydration reaction, we see that only for protonated GInAla is the mechanism analogous, where the same nucleophilic attack on the side chain takes place during both fragmentation reactions. This is in line with the dehydration reaction of aspartic acid and glutamic acid, where the side chain is attacked by the N-terminus [25]. The assigned structure for protonated GInAla is not $a b_{2}$ ion structure but is in agreement with reported structures $[55,57,58]$. A diketopiperazine structure has also been found for the $b_{2}$ ion of AsnAlaAla [3,9]. For AlaAsnAla the formation of a succinimide structure (which involves the side chain) has been reported [3], but this structure was not identified in the dipeptides that contain asparagine in the work presented here. The assigned oxazolone structure for $\mathrm{H}_{2} \mathrm{O}$-loss from protonated AsnAla is in agreement with the oxazolone structure for AsnGly- $\mathrm{H}_{2} \mathrm{O}$ previously proposed [38]. However, no bifurcating mechanism to both an oxazolone and diketopiperazine stucture after water loss was proposed [38]. Dehydration of protonated AlaAsn forms the $b_{2}$-ion and does not involve the Asn side chain, in contrast to $b_{2}$ formation from protonated AlaAsnAla, where the Asn side chain is involved in the formation of a succinimide structure[3]. This suggests that the identity of the third residue is of influence in the formation of $b_{2}$ type ions. Detailed transition state calculations are required to explain these observations, where the present structural identification may be used to guide such calculations.

On the basis of the calculated relative Gibbs free energies, the diketopiperazine structures are consistently the lowest energy structures. The observed oxazolone structures have higher relative free energies (48 $-73 \mathrm{~kJ} / \mathrm{mol}$ ), but are often suggested to form more likely because of kinetic arguments 
$[9,35,60]$. $[9,17,61-63]$. Here, we find that for the Asn-containing peptides, $\mathrm{H}_{2} \mathrm{O}$-loss produces both diketopiperazine and oxazolone structures.

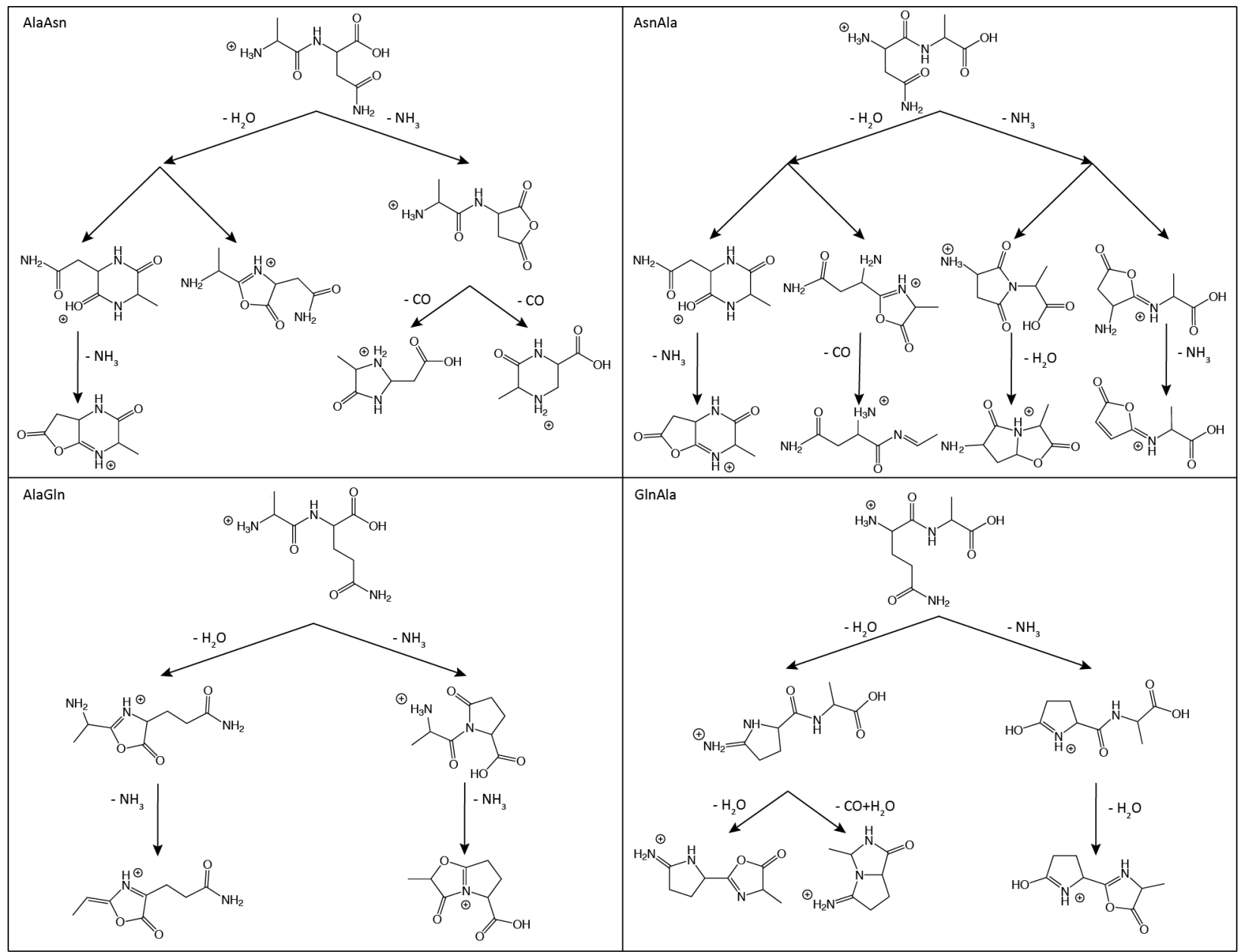

Figure 5. Molecular structure map of deamidation [16] and dehydration reactions in the Asn and Gln containing protonated dipeptides based on the spectroscopically identified fragment ion structures established.

\section{Acknowledgments}

The authors gratefully acknowledge the excellent technical support of the FELIX staff. Financial support for this project was provided by NWO Chemical Sciences under VICI project nr. 724.011.002. The authors also thank NWO Physical Sciences (EW) and the SARA Supercomputer Center for providing the computational resources under grant no. 15408 and JO thanks the Stichting Physica. This work is part of the research program of FOM, which is financially supported by NWO. 


\section{References}

[1] W. Li, C. Song, D.J. Bailey, G.C. Tseng, J.J. Coon, V.H. Wysocki. Statistical Analysis of Electron Transfer Dissociation Pairwise Fragmentation Patterns. Anal. Chem. 83 (2011) 9540-9545.

[2] J. Grzetic, J. Oomens. Effect of the Asn side chain on the dissociation of deprotonated peptides elucidated by IRMPD spectroscopy. Int. J. Mass Spectrom. 354-355 (2013) 70-77.

[3] J. Grzetic, J. Oomens. Spectroscopic Identification of Cyclic Imide b2-ions from peptides containing GIn and Asn Residues. J. Am. Soc. Mass Spectrom. 24 (2013) 1228-1241.

[4] R. Aebersold, D.R. Goodlett. Mass Spectrometry in Proteomics. Chem. Rev. 101 (2001) 269-296.

[5] H. Steen, M. Mann. The ABC's (and XYZ's) of peptide sequencing. Nat. Rev. 5 (2004) 699-711.

[6] J.R. Yates. Mass Spectrometry and the Age of the Proteome. J. Mass Spectrom. 33 (1998) 1-19.

[7] P. Roepstorff, J. Fohlman. Proposal for a common nomenclature for sequence ions in mass spectra of peptides. Biom. Mass Spectrom. 11 (1984) 601.

[8] B. Paizs, S. Suhai. Fragmentation Pathways of Protonated Peptides. Mass Spec. Rev. 24 (2005)

[9] L.J. Morrison, J. Chamot-Rooke, V.H. Wysocki. IR action spectroscopy shows competitive oxazolone

and diketopiperazine formation in peptides depends on peptide length and identiy of terminal residue in the departing fragment. Analyst. 139 (2014) 2137-2143.

[10] A.R. Dongre, J.L. Jones, A. Somogyi, V.H. Wysocki. Influence of peptide composition, gas-phase basicity, and chemical modification on fragmentation efficiency: Evidence for the mobile proton model.

J. Am. Chem. Soc. 118 (1996) 8365-8374.

[11] V.H. Wysocki, G. Tsaprailis, L.L. Smith, L.A. Breci. Mobile and localized protons: a framework for understanding peptide dissociation. J. Mass Spectrom. 35 (2000) 1399-1406.

[12] R. Boyd, A. Somogyi. The mobile proton hypothesis in fragmentation of protonated peptides: a perspective. J. Am. Soc. Mass Spectrom. 21 (2010) 1275-1278.

[13] R. Spezia, J. Martens, J. Oomens, K. Song. Collision-induced dissociation pathways of protonated Gly2NH2 and Gly3NH2 in the short time-scale limit by chemical dynamics and ion spectroscopy. Int. J. Mass Spectrom. 388 (2015) 40-52.

[14] C.K. Barlow, R.A.J. O'Hair. Gas-phase peptide fragmentation: how understanding the fundamentals provides a springboard to developing new chemistry and novel proteomic tools. J. Mass Spectrom. 43 (2008) 1301-1319.

[15] J.M. Farrugia, R.A.J. O'Hair, G.E. Reid. Do all b2 ions have oxazolone structures? Multistage mass spectrometry and ab initio studies on protonated $\mathrm{N}$-acyl amino acid methyl ester model systems. Int. J Mass Spectrom. 210-211 (2001) 71-87.

[16] L.J.M. Kempkes, J. Martens, J. Grzetic, G. Berden, J. Oomens. Deamidation reactions of asparagine and glutamine containing dipeptides investigated by ion spectroscopy. J. Am. Soc. Mass Spectrom. 27 (2016) 1855-1869.

[17] N.C. Polfer, J. Oomens, S. Suhai, B. Paizs. Spectroscopic and Theoretical Evidence for Oxazolone Ring Formation in Collision-Induced Dissociation of Peptides. J. Am. Chem. Soc. 127 (2005) 17154-17155. [18] N.C. Polfer, J. Oomens, S. Suhai, B. Paizs. Infrared Spectroscopy and Theoretical Studies on GasPhase Protonated Leu-enkephalin and its fragments: direct experimental evidence for the mobile proton. J. Am. Chem. Soc. 129 (2007) 5887-5897.

[19] G. Frison, G. van der Rest, F. Turecek, T. Besson, J. Lemaire, P. Maître, J. Chamot-Rooke. Structure of Electron-Capture Dissociation Fragments from Charge-Tagged Peptides Probed by Tunable Infrared Multiple Photon Dissociation. J. Am. Chem. Soc. 130 (2008) 14916-14917.

[20] S.H. Yoon, J. Chamot-Rooke, B.R. Perkins, A.E. Hilderbrand, J.C. Poutsma, V.H. Wysocki. IRMPD Spectroscopy Shows That AGG Forms an Oxazolone b(2)(+) Ion. J. Am. Chem. Soc. 130 (2008) 1764417645. 
[21] J. Oomens, S. Young, S. Molesworth, M. van Stipdonk. Spectroscopic Evidence for an Oxazolone Structure of the b2 Fragment Ion from Protonated Tri-Alanine. J. Am. Soc. Mass Spectrom. 20 (2009) 334-339.

[22] B.J. Bythell, U. Erlekam, B. Paizs, P. Maître. Infrared Spectroscopy of Fragments from Doubly Protonated Tryptic Peptides. Chem. Phys. Chem. 10 (2009) 883-885.

[23] N.C. Polfer, J. Oomens. Reaction products in mass spectrometry elucidated with infrared spectroscopy. Phys. Chem. Chem. Phys. 9 (2007) 3804-3817.

[24] N.C. Polfer, J. Oomens. Vibrational Spectroscopy of Bare and Solvated Ionic Complexes of Biological Relevance. Mass Spectrom. Rev. 28 (2009) 468-494.

[25] L.J.M. Kempkes, J.K. Martens, G. Berden, J. Oomens. Deamidation reactions of protonated asparagine and glutamine investigated by ion spectroscopy. Rapid Commun. Mass Spectrom. 30 (2016) 483-490.

[26] B. Lucas, G. Grégoire, J. Lemaire, P. Maître, J. Ortega, A. Rupenyan, B. Reimann, J.P. Schermann, C. Desfrançois. Investigation of the protonation site in the dialanine peptide by infrared multiphoton dissocation spectroscopy. Phys. Chem. Chem. Phys. 6 (2004) 2659-2663.

[27] A.L. Patrick, C.N. Stedwell, B. Schindler, I. Compagon, G. Berden, J. Oomens, N.C. Polfer. Insights into the fragmentation pathways of gas-phase protonated sulfoserine. J. Mass Spectrom. 379 (2015) 2632.

[28] J. Oomens, J.D. Steill, B. Redlich. Gas-Phase IR Spectroscopy of deprotonated Amino Acids. J. Am. Chem. Soc. 131 (2009) 4310-4319.

[29] C.F. Correia, P.O. Balaj, D. Scuderi, P. Maître, G. Ohanessian. Vibrational Signatures of Protonated, Phosphorylated Amino Acids in the Gas Phase. J. Am. Chem. Soc. 130 (2008) 3359-3370.

[30] Y.M.E. Fung, T. Besson, J. Lemaire, P. Maître, R.A. Zubarev. Room-Temperature Infrared Spectroscopy Combined with Mass Spectrometry Distinghuishes Gas-Phase Protein Isomers. Angew. Chem. 48 (2009) 8340-8342.

[31] U. Erlekam, B.J. Bythell, D. Scuderi, M. van Stipdonk, B. Paizs, P. Maître. Infrared Spectroscopy of Fragments of Protonated Peptides: Direct Evidence for Macrocyclic Structure of b5 ions. J. Am. Chem. Soc. 131 (2009) 11503-11508.

[32] J.M. Farrugia, T. Taverner, R.A.J. O' Hair. Side-chain involvement in the fragmentation reactions of the protonated methyl esters of histidine and its peptides. Int. J. Mass Spectrom. 209 (2001) 99-112.

[33] R.K. Sinha, U. Erlekam, B.J. Bythell, B. Paizs, P. Maître. Diagnosing the Protonation Site of b2 Peptide Fragment lons Using IRMPD in the $\mathrm{X}-\mathrm{H}(\mathrm{X}=\mathrm{O}, \mathrm{N}$ and $\mathrm{C})$ Stretching Region. J. Am. Chem. Soc. Mass Spectrom. 22 (2011) 1645-1650.

[34] G.E. Reid, R.J. Simpson, R.A.J. O'Hair. A Mass Spectrometric Ab Initio Study of the Pathways for Dehydration of Simple Glycine and Cysteine-Containing Peptide [M+H]+ Ions. J. Am. Soc. Mass Spectrom. 9 (1998) 945-956.

[35] B. Balta, V. Aviyente, C. Lifshitz. Elimination of Water from the Carboxyl Group of GlyGlyH+. J. Am. Chem. Soc. 14 (2003) 1192-1203.

[36] K.D. Ballard, S.J. Gaskell. Dehydration of Peptide [M+H]+ lons in the Gas Phase. J. Am. Soc. Mass Spectrom. 4 (1993) 477-481.

[37] S. Zou, J. Oomens, N.C. Polfer. Competition between diketopiperazine and oxazolone formation in water loss products from protonated ArgGly and GlyArg. Int. J. of Mass Spectrom. 316-318 (2012) 12-17.

[38] G.C. Boles, R.R. Wu, M.T. Rodgers, P.B. Armentrout. Thermodynamics and Mechanisms of Protonated Asparaginyl-Glycine Decomposition. J. Phys. Chem. B. 120 (2016) 6525-6545.

[39] B.R. Perkins, J. Chamot-Rooke, S.H. Yoon, A.C. Gucinski, A. Somogyi, V.H. Wysocki. Evidence of dikeopiperazine and oxazolone structures for HA b2+ ion. J. Am. Chem. Soc. 131 (2009) 17528-17529. 
[40] U.H. Verkerk, J. Zhao, M.J. van Stipdonk, B.J. Bythell, J. Oomens, A.C. Hopkinson, K.W.M. Siu. Structure of the $[\mathrm{M}+\mathrm{H}-\mathrm{H} 2 \mathrm{O}]+$ ion from tetraglycine: A revisit by means of density functional theory and isotope labeling. J. Phys. Chem. A 115 (2011) 6683-6687.

[41] J. Martens, J. Grzetic, G. Berden, J. Oomens. Structural identification of electron transfer dissociation products in mass spectrometry using infrared ion spectroscopy. Nature Communications 7 (2016) 11754.

[42] J. Martens, G. Berden, C.R. Gebhardt, J. Oomens. Infrared ion spectroscopy in a modified quadrupole ion trap mass spectrometer at the FELIX free electron laser laboratory. Rev. of Scient. Instrum. 87 (2016)

[43] D. Oepts, A.F.G. v.d. Meer, P.W. v. Amersfoort. The Free-Electron-Laser User Facility FELIX. Infrared Phys. Technol. 36 (1995) 297-308.

[44] J.K. Martens, J. Grzetic, G. Berden, J. Oomens. Gas-phase conformations of small polyprolines and their fragment ions by IRMPD spectroscopy. Int. J. of Mass Spectrom. 377 (2015) 179-187.

[45] J. Oomens, B.G. Sartakov, G. Meijer, G. von Helden. Gas-phase infrared multiple photon dissociation spectroscopy of mass-selected molecular ions. Int. J Mass Spectrom. 254 (2006) 1-19.

[46] M.J. Frisch, G.W. Trucks, H.B. Schlegel, G.E. Scuseria, M.A. Robb, J.R. Cheeseman, G. Scalmani, V. Barone, B. Mennucci, G.A. Petersson, H. Nakatsuji, M. Caricato, X. Li, H.P. Hratchian, A.F. Izmaylov, J. Bloino, G. Zheng, J.L. Sonnenberg, M. Hada, M. Ehara, K. Toyota, R. Fukuda, J. Hasegawa, M. Ishida, T. Nakajima, Y. Honda, O. Kitao, H. Nakai, T. Vreven, J. Montgomery, J.A., J.E. Peralta, F. Ogliaro, M. Bearpark, J.J. Heyd, E. Brothers, K.N. Kudin, V.N. Staroverov, R. Kobayashi, J. Normand, K. Raghavachari, A. Rendell, J.C. Burant, S.S. Iyengar, J. Tomasi, M. Cossi, N. Rega, N.J. Millam, M. Klene, J.E. Knox, J.B. Cross, V. Bakken, C. Adamo, J. Jaramillo, R. Gomperts, R.E. Stratmann, O. Yazyev, A.J. Austin, R. Cammi, C. Pomelli, J.W. Ochterski, R.L. Martin, K. Morokuma, V.G. Zakrzewski, G.A. Voth, P. Salvador, J.J. Dannenberg, S. Dapprich, A.D. Daniels, O. Farkas, J.B. Foresman, J.V. Ortiz, J. Cioslowski, D.J. Fox. Gaussian09, RevisionA.1. Gaussian, Inc., Wallingford, CT (2009)

[47] D.A. Case, T. Darden, T.E. Cheatham III, C. Simmerling, J. Wang, R.E. Duke, R. Luo, R.C. Walker, W. Zhang, K.M. Merz, B.P. Roberts, S. Hayik, A. Roitberg, G. Seabra, J. Swails, A.W. Goetz, I. Kolossváry, K.F. Wong, F. Paesani, J. Vanicek, R.M. Wolf, J. Liu, X. Wu, S.R. Brozell, T. Steinbrecher, H. Gohlke, Q.X. Cai Ye, J. Wang, M.-J. Hsieh, G. Cui, D.R. Roe, D.H. Mathews, M.G. Seetin, R. Salomon-Ferrer, C. Sagui, V. Babin, T. Luchko, S. Gusarov, A. Kovalenko, P.A. Kollman. AMBER. University of California, San Francisco (2012) [48] J.M. Headrick, E.G. Diken, R.S. Walters, N.I. Hammer, C. R.A., J. Cui, E.M. Myshakin, M.A. Duncan, M.A. Johnson, K.D. Jordan. Spectral Signatures of Hydrated Proton Vibrations in Water Clusters. Science 308 (2005) 1765-1769.

[49] P. Hurtado, F. Gamez, H. S., B. Martinez-Haya, J.D. Steill, J. Oomens. Crown Ether Complexes with $\mathrm{H} 3 \mathrm{O}+$ and NH4+: Proton Localization and Proton Bridge Formation. J. Phys. Chem. A 115 (2011) 72757282.

[50] X. Li, J. Oomens, J.R. Eyler, D.T. Moore, S.S. Iyengar. Isotope dependent, temperature regulated, energy repartitioning in a low-barrier, short-strong hydrogen bonded cluster. J. Chem. Phys. 132 (2010) 244301.

[51] J.M. Headrick, J.C. Bopp, M.A. Johnson. Predissociation spectroscopy of the argon-solvated H5O2+ "zundel" cation in the 1000-1900 cm-1 region. J. Chem. Phys. 121 (2004) 11523-11526.

[52] T.D. Fridgen, L. MacAleese, P. Maitre, T.B. McMahon, P. Boissel, J. Lemaire. Infrared spectra of homogeneous and heterogeneous proton-bound dimers in the gas phase. Phys. Chem. Chem. Phys. 7 (2005) 2747-2755.

[53] T.D. Fridgen, T.B. McMahon, L. MacAleese, J. Lemaire, P. Maitre. Infrared Spectrum of the Protonated Water Dimer in the Gas Phase. J. Phys. Chem. A 108 (2004) 9008-9010.

[54] V.H. Wysocki, K.A. Resing, Q. Zhang, G. Cheng. Mass spectrometry of peptides and proteins. Methods 35 (2005) 211-222. 
[55] B. Godugu, P. Neta, Y. Simon-Manso, S.E. Stein. Effect of N-Terminal Glutamic Acid and Glutamine on Fragmentation of Peptide lons. J. Am. Soc. Mass Spectrom. 21 (2010) 1169-1176.

[56] N.N. Dookeran, T. Yalcin, A.G. Harrison. Fragmentation reactions of protonated alpha-amino acids. Journal of Mass Spectrometry. J. Mass Spectrom. 31 (1996) 500-508.

[57] A.G. Harrison. Fragmentation reactions of protonated peptides containing glutamine or glutamic acid. J. Mass Spectrom. 38 (2003) 174-187.

[58] P. Neta, Q. Pu, L. Kilpatrick, X. Yang, S.E. Stein. Dehydration Versus Deamination of N-Terminal Glutamine in Collision-Induced Dissociation of Protonated Peptides. J. Am. Soc. Mass Spectrom. 18 (2007) 27-36.

[59] M.A. Baldwin, A.M. Falick, B.W. Gibson, S.B. Prusiner, N. Stahl, A.L. Burlingame. Tandem mass spectrometry of peptides with $\mathrm{N}$-terminal glutamine: Studies on a prion protein peptide. J. Am. Soc. Mass Spectrom. 1 (1990) 258-264.

[60] P.B. Armentrout, A.L. Heaton. Thermodynamics and Mechanisms of Protonated Diglycine Decomposition: A Computational Study. J. Am. Chem. Soc. 23 (2012) 621-632.

[61] T. Yalcin, I.G. Csizmadia, M.R. Peterson, A.G. Harrison. The structure and fragmentation of bn $(n \geq 3)$ ions in peptide spectra. J.Am. Soc. Mass Spectrom. 7 (1996) 233-242.

[62] M.J. Nold, C. Wesdemiotis, T. Yalcin, A.G. Harrison. Amide bond dissociation in protonated peptides. Structures of the N-terminal ionic and neutral fragments. Int. J. Mass Spectrom. Ion Processes 164 (1997) 137-153.

[63] B. Paizs, S. Suhai. Combined quantum chemical and RRKM modeling of the main fragmentation pathways of protonated GGG. II. Formation of b2, y1, and y2 ions. Rapid Commun. Mass Spectrom. 16 (2002) 375-389. 